\title{
Immigration Policy in the Crossfire of Neoliberalism and Neonationalism
}

\author{
Christian Joppke*
}

Abstract: Previous scholarship has looked at Western states' immigration policies from the vantage point of advancing liberalism. This perspective needs to be updated by including two additional factors: neoliberalism and a new nationalism that arises in its context, typically in the form of populist right parties. I argue that contemporary immigration policy is bifurcated into two policies with opposite logics: one of proactively courting the top, and another of reactively fending off the bottom. This dual structure is best explained in neoliberal terms, with neonationalism merely reinforcing but not generating it.

Keywords: Immigration policy, high-skilled migration, low-skilled migration, neoliberalism, nationalism.

\section{Einwanderungspolitik in Kreuzfeuer von Neoliberalismus und Neonationalismus}

Zusammenfassung: Bislang wurden die Einwanderungspolitiken westlicher Staaten vor allem unter dem Gesichtspunkt eines fortschreitenden Liberalismus untersucht. Es gibt aber zwei weitere Faktoren, die auf diese Politiken zunehmend Einfluss nehmen: Neoliberalismus und ein neuer Nationalismus, der im Kontext der neoliberalen Globalisierung entsteht. In diesem Kräftefeld nimmt die Einwanderungspolitik eine duale Struktur an, einerseits eine hochqualifizierte Elite zu umwerben, und andererseits die weniger qualifizierte Masse zurückzuweisen. Diese duale Struktur ist hauptsächlich neoliberal bedingt und motiviert, und der Neonationalismus verstärkt aber generiert sie nicht.

Schlüsselwörter: Einwanderungspolitik, hochqualifizierte Migration, niedrig-qualifizierte Migration, Neoliberalismus, Nationalismus

\section{La politique d'immigration dans le feu croisé du néolibéralisme et du néonationalisme}

Résumé: Jusqu'à présent, les politiques d'immigration des États occidentaux ont été examinées principalement sous l'angle du libéralisme progressif. Toutefois, deux autres facteurs influencent de plus en plus ces politiques: le néolibéralisme et un nouveau nationalisme qui émerge dans le contexte de la mondialisation néolibérale. Dans ce champ de force, la politique d'immigration revêt une double structure, d'une part en courtisant une élite hautement qualifiée, et d'autre part en rejetant les masses moins qualifiées. Cette double structure est principalement de nature néolibérale, et le néo-nationalisme la renforce mais ne la génère pas. Mots-clés: Politique migratoire, migration hautement qualifiée, migration peu qualifiée, néolibéralisme, nationalisme

Institute of Sociology, University of Bern, CH-3012 Bern, joppke@soz.unibe.ch 
Western states' immigration policies have previously been looked at from the vantage point of advancing liberalism, according to which these policies have become less racist and more universalistic, selecting migrants on the basis of individual rather than group-level attributes (e. g. Freeman 1995; Joppke 2005). This perspective needs to be updated by factoring-in two new forces that impinge on a liberal immigration policy: neoliberalism and a new nationalism that is generated in a neoliberal context, typically in the form of right-wing populism. Over the past few decades, a neoliberal order, in sync with globalization, has come into its own, which economizes social relations and minimizes the role of social justice (see Hayek 1982). As I shall argue, it has left its mark on immigration policy, which has become bifurcated into two separate, rather opposite-minded types of policy: on the one hand, a policy of courting the top, that is, the competitive recruitment of high-skilled migrants; on the other hand, a policy of fending off the bottom, that is, a restrictive posture toward the rest, which is processed in a variety of legal ways, as low-skilled, family, asylum, or irregular migration. Into this new constellation enters the force of neonationalism, which is a reactive movement to neoliberalism and the globalization that the latter has ideologically undergirded. Gaining strength in Europe over the last few decades in the form of radical right parties and populism, neonationalism had its dramatic breakthrough in the double shock of 2016, delivered by the successful Brexit referendum in the UK and the rise of Trump in the US. Both of these events thrived on hostility to (certain kinds of) immigration. So the question is: What happened to liberal immigration policy in the crossfire of neoliberalism and neonationalism?

In a first step, I argue that any reflection on immigration policy must start from the restrictive imperative that underlies this policy, which makes it difficult to establish what a "liberal" immigration policy is. In a second step, I review several recent global surveys of changing immigration policies, which converge in stressing the neoliberalism factor. Indeed, as I argue in the third (and main) step, the dual structure of contemporary immigration policy, which is to court the top and fend off the bottom, is fully accountable in neoliberal terms, including its restrictive elements. Neonationalism, as I claim in the fourth (and final) step, while often believed to have profound impact on contemporary immigration policy, has remained peripheral to it.

\section{The Restrictive Imperative}

Any reflection on immigration policy must start with acknowledging the restrictive imperative that is built into it, up to a point that the notion of a liberal immigration policy appears to be a contradiction in terms. Always many more have to be rejected 
than could ever be admitted. There are no clean hands in immigration policy. Aristide Zolberg $(2006,13)$ noted that on a "hypothetical continuum ranging from 'open' to 'closed", the immigration policies across capitalist democracies are "clustered very narrowly around the 'closed' pole", even in a classic immigrant country like the United States: “(T)he contemporary regime retains a 'near-zero baseline' with regard to the supply of entries in relation to the demand for them" (ibid., 13f.). According to Zolberg, the restrictive immigration regime is due to two factors: the "Westphalian" state system that is premised on strictly guarded borders, movement across which is always the exception; and global inequality, which leads rich countries to use borders to shore-up their "privileged position", protecting not least those who are less privileged internally, such as workers (ibid., 14). With globalization marching on in the new millennium, Zolberg might have added that the wealthpreserving function of borders has come under attack less by immigrants than by capital moving on to places where labor is cheap and pliable. In one account, capital mobility even explains why low-skilled migration is "more restricted" in today's second globalization than it was during the late $19^{\text {th }}$-century's first globalization: "(T)he easier it is for a firm to move its factory to another country, the less likely it is to support open immigration at home" (Peters 2017, 3).

Henry Sidgwick, a prominent $19^{\text {th }}$ century liberal, deemed the "cosmopolitan ideal" as "perhaps the ideal of the future", but he found that at present the "national ideal [] of political organization prevailed" $(1891,295)$. And it is good this way because only on the "national" basis it is possible to achieve "internal cohesion" and to "raise the standard of living among the poorer classes" (ibid., 296). Accordingly, the nature of immigration policy, which in Sidgwick's classic textbook, The Elements of Politics, interestingly is treated in a chapter on the "principles of international duty", is "the right to admit aliens on its own terms, imposing any conditions on entrance or any tolls on transit, and subjecting them to any legal restrictions or disabilities that it (the state, CJ) may deem expedient" (ibid., 235). For Sidgwick this followed from the international law principle of "mutual non-interference", the only restriction to which is to give foreigners "due warning ... and due time ... for withdrawal" (ibid.). This brutish-sounding statement by a $19^{\text {th }}$ century liberal shows how much the meaning of liberal has in the meantime evolved toward the "cosmopolitan ideal".

But what Sidgwick dubbed the "national ideal" is still the dominant principle of political organization today, and it shapes the parameters of immigration policy. This becomes clear when perusing putatively "liberal" solutions to contemporary migration dilemmas. In one plausible account, provided by one of the liberal world's leading pro-migration voices, The Economist, the current situation looks like this: 
(S)ince rich countries admit virtually no economic migrants from poor countries unless they have exceptional skills or family ties, many of them try their luck by posing as refugees. ${ }^{1}$

Moreover, this occurs in a context where, as Harvard economist Richard Freeman confirms, "most of the gains from immigration accrue to the immigrants rather than to the residents of destination countries" $(2006,165)$. This situation leaves only two logical responses for receiving states: Admit more low- or unskilled migrants for whom there is only limited need and who are resented by virtually all Western mass publics, especially their lower-class portions who feel threatened by neoliberal globalization; or enforce existing asylum rules against migrants who "try their luck by posing as refugees". ${ }^{2}$ This "liberal" way of describing the situation may differ in degree, but not in kind from the "fake" or "bogus" refugees conjured up by the radical right. But it rings true. Consider that almost half of new asylum-seekers in Germany in 2018 were under 18 years of age (SVR 2019, 32-33), and the large majority of them are male. It is unlikely that the "well-founded fear of persecution", which is the official refugee definition, should be concentrated in a group that by age and physical constitution deems itself strong enough to brave the perilous waters that need to be crossed first.

What is the "liberal" way of dealing with this situation? Certainly, The Economist's (neo)liberal bottom line is that "migration can make the world richer" 3 , and in one optimistic scenario unhindered international mobility would double the global GDP. ${ }^{4}$ But the concrete proposals to get from here to there do not look so liberal at all, as they need to pass the threshold of democratic approval: strict law enforcement, first; and lesser rights for migrants, second. With respect to the first, "regaining control" means "to secure borders and enforce laws", for instance, by clamping down on "illegal immigrants" and "deporting those denied asylum". 5 Again, no populist or nationalist would disagree. Of course, opinions divide on the demand for "open routes for well-regulated economic migration", the promoting of which to skeptical mass publics, in the realist liberal's reckoning, requires "toughness" at the border. ${ }^{6}$ With respect to high-skilled immigration, which today is favored by the majority of OECD states, Donald Trump and Europe's radical right are in agreement:

I want to go to a merit-based system. Actually two countries that have very strong systems are Australia and Canada. And I like those systems very much, they're very strong, they're very good, I like them very much. ${ }^{7}$

"A Way Forward on Immigration", The Economist, 25 August 2018, p. 10.

Ibid.

"Crossing Continents", The Economist, 25 August 2018, p. 14.

"A World of Walls", The Economist, 16 November 2019, p. 3.

"A Way Forward on Immigration", op. cit.

Ibid.

“Transcript: Interview with Donald Trump", The Economist, 11 May 2017. 
Similarly, to admit "qualified migration according to need" has been a surprisingly non-demagogic entry in an otherwise rabidly anti-immigrant and anti-Muslim 2017 election program of the populist right Alternative for Germany (AfD 2017, 29).

The crux is obviously low-skilled immigration. Unwanted by most states, except in tightly controlled doses, the overwhelming supply of this migration is either irregular or redirected to the asylum and family-unification channels, which has made the latter the targets of increasing restrictiveness for some decades now, in Europe and in the classic immigration countries alike. Considering that the world's supply of low-skilled migrants vastly exceeds the demand for them, and further considering that the sociology of migration has solidly corroborated the fact that migration begets more migration (via "cumulative causation", Massey et al. 1993, 451), it is not surprising that no Western state has as yet pulled off the feat of a sustainable low-skilled immigration policy that would remove pressure from the overcharged asylum- and family migration channels and thus allow states to become more generous and "liberal" in managing the latter.

For low-skilled migrants in "high-income states", as Martin Ruhs (2013) has argued provocatively, a "numbers v. rights" logic applies. It means that accepting more requires granting them lesser rights, including enforcing their return. States without a human rights tradition, like the Gulf States, South Korea, or Singapore, do so without much ado, systematically preventing low-skilled migrants from being joined by even close family (like spouses or dependent children) and barring them from permanent residence, not to mention citizenship. Western states, which are internally beholden to human rights and equality norms, have many more scruples in this respect. It is revealing that Ruhs' notionally hard-nosed "rejection of rights fetishism" (ibid., 165) quickly collapses, and that he advocates the right for lowskilled temporary labor migrants to accede to permanent residence and citizenship after only four years (ibid., 172-178) - this is even more generous than current liberal state practice, which in the European Union is after 5 years.

Next to stricter law enforcement, The Economist's second not-so-liberal proposal for "a way forward on immigration" embraces the controversial numbers $\mathrm{v}$. rights argument. The recommendation is that "migrants" have only limited access to welfare benefits, also to make sure that they get into work quickly - a notorious problem in Europe, but not in the classic immigrant countries with their flexible labor markets and slimmer welfare schemes. Furthermore, on the assumption that it is mainly migrants who profit from migration, why not make them pay higher income taxes or charge them an entrance fee, as neoliberal economists like Gary Becker have long suggested? ${ }^{8}$ However, the indiscriminate talk of "migrants" in this context glosses over the fact that such grading of rights works only for their lower-skilled part. For high-skilled migrants, an opposite logic of "competitive immigration regimes" (Shachar 2006) applies, which has even moved some states to

8 "A Way Forward on Immigration", op. cit.; "Crossing Continents", op. cit., p. 16. 
offer tax privileges to high-skilled immigrants that citizens and other residents do not enjoy. In Denmark, for instance, where under the thrall of the populist right Danish People's Party the family rights of low-skilled (and low-earning) immigrants have been heavily restricted, high-earning immigrants pay lower taxes than citizens, at least in their first three years of residence - which does not seem to bother the populists (Kleven et al. 2014, 333-339). The important matter is that the "liberal" proposal of lesser rights for low-skilled migrants to make them socially acceptable is not so different from the "welfare chauvinism" that radical right parties have come to subscribe to in recent years (see Careja et al. 2016, 436).

This is not to deny that nuance and degree matter. There are important differences between radical right and realist-liberal ways of dealing with immigration. Just consult the average radical right party manifesto. The Alternative for Germany, for instance, advocates an "immediate closing of the borders" to stop "unregulated mass immigration into our country and into its welfare system by predominantly unskilled asylum-seekers" (AfD 2017, 29). Furthermore, their alarmist demand for the "self-preservation" (Selbsterhaltung) of the German "people" (Volk) in light of a looming "mass exodus" (Völkerwanderung) from Africa has a not-so-subtle racial inflection (ibid., 28), as has its demonic picture of Islam as "a big threat", as "not belonging to Germany", and as in irreconcilable "conflict with the liberaldemocratic order" (ibid., 33-35). In the same genre, the Austrian populist right FPÖ opposes "any kind of Zuwanderung (in-migration)" (conceding, however, to "grant asylum"); it considers Islam "not a part of Austria"; and it favors the "sectoral closure of the Austrian labor market for EU-foreigners and third state nationals to protect domestic employees", which is in flat contradiction with EU law (FPÖ 2017). So is the French Front National's (since 2018 Rassemblement National) call for inscribing the "national priority" into the French constitution (FN 2017). The list of radical right demands that conflict with constitutional and statutory realities could be easily prolonged - including "welfare chauvinism" proper, which draws a sharp line between (putatively co-ethnic) citizens and permanent residents that none of the mentioned "numbers v. rights" proposals would condone (whose main dividing line is between temporary migrants and all others, the latter comprising citizens and permanent residents).

\section{Theorizing Immigration Policy: From Liberal to Neoliberal}

In light of the restrictive imperative, which even liberals must embrace (unless they advocate cosmopolitanism), one realizes the immense provocation inherent in the single most influential political science statement on immigration policy in liberal democracies, which is by Gary Freeman (1995). Freeman argued that, due to a liberal interest-group dynamic and a liberal non-discrimination norm, immigration 
policy is in reality "broadly expansionist and inclusive", so that restrictiveness is little more than political elite rhetoric. Conceiving his argument in the first half of the 1990s, Freeman does not mention at all the low- v. high-skilled migrant distinction, which - I shall argue - in the meantime has become the central axis of immigration policy, in effect fragmenting the latter into (a minimum of) two policies, each taking a rather different direction.

A recent comparison of broadly conceived "migration policies" in 45 (mostly OECD) countries since 1945 still confirms Freeman's diagnosis of general policy "liberalization", which merely "decelerated" but was not reversed in the post-1990s period of increased politicization and neonationalist mobilization (De Haas et al. 2016, 334). ${ }^{9}$ Yet the real message of Hein de Haas et al. $(2016,353)$ is that immigration policies are becoming ever more complex and selective:

(M)igration regimes have not become more restrictive, but rather increasingly complex through a differentiation of policy instruments and a growing emphasis on criteria such as skills as a tool for migrant selection.

A further stated decline of ethnic and nationality-based selection criteria is particularly noteworthy, unless the discriminatory direction is positive (as in the EU or Mercosur free movement regimes); and, parallel to this, there has been a rise of class-based selection criteria, such as skills, education, and wealth, which bears the imprint of neoliberalism. The result is a world of "stratified" and "selective" mobility, marked by a "tension between restrictive closure (for the many) and selective opening (for the few)" (ibid., 179). Pioneered by the Canadian points system, the spirit of merit-based migration regimes is "technocratic, econometric, and managerial", while "explicit discrimination on ... grounds (of)... race, ethnicity, and national origin is strictly prohibited" (ibid., 183, 188). Skill-selective migration policy obviously combines a neoliberal utility with a liberal rights logic; there is no mentioning by De Haas et al. of a nationalist exclusion logic working against or impinging on it.

Similarly, a rather dark diagnosis of "global convergence" toward a "new mean-spirited politics of immigration", by Catherine Dauvergne (2016, 2), does entirely without factoring in resurgent nationalism. This is all the more astonishing as the three factors identified by her as bringing about this global convergence: the asylum crisis, the fear of Islamic fundamentalism, and the end of multiculturalism, have all been central to neonationalist mobilization. In her narrative, neoliberalism does all the dirty work. According to it, there is a "competitive migration convergence" from North America to Europe, centering around the dualism of attracting high-skilled immigrants and keeping out (low-skilled) asylum seekers and family migrants. Much like Ayelet Shachar, for whom a liberal-cum-neoliberal "selecting by merit" has replaced "selecting by origin" (2016), Dauvergne observes that

$9 \quad$ For De Haas et al. (2016), "migration policies" comprise (entry and exit) control, selection, and integration policies. 
neoliberal immigration policy is still in a liberal "non-discriminating" attitude, ignoring "cultural, ethnic, and even racial values" in favor of a "neutral selection" on the basis of merit-rewarding schemes $(2016,174)$. Still, the perplexing result of merit-based migration is that "people cannot migrate in search of a better life; they migrate because they have a better life" (ibid., 175). This inverts the "traditional logic of immigration", not only in the North American settler regimes, according to which people move to improve their lives.

The center of Dauvergne's gloomy picture is what she calls the "loss of settlement". Even a classic "settler society" like Canada has moved away from a preference for permanent to one for temporary migrants, whereby it appropriates the European practice. In 2006, Canada for the first time admitted more temporary migrants than permanent immigrants, increasingly asking its newcomers - now preferentially acquired through the student route - to gradually "earn" their right to permanent residence, while this status may be lost at any time through "bad" behavior on their part (Dauvergne 2016, 127). Dauvergne calls the new phenomenon "trial migration", which is driven by an economistic logic that "states no longer need people but rather "widgets" (ibid.). Dauvergne's "new politics of immigration" bears the undeniable mark of neoliberalism, a shrunken form of liberalism that abhors discrimination yet reduces the individual to her economic uses and that is austere and disciplining rather than justice-oriented (see the compelling critique of neoliberalism by Brown 2015). While perhaps no novelty in Europe, with its "guest-worker" legacy, this does seem to be new in a "normative immigration country" that had previously looked at immigration policy more holistically as "selecting parents of future citizens" (Macklin 2017, 286).

Confirming the neoliberal trend in immigration policy, a global comparison of "migration regimes" 10 in 30 major immigrant-receiving countries, by Anna Boucher and Justin Gest (2018, ch.1), found them evolving from a "liberal model" toward a "market model". In the "liberal model", the expectation was that immigrants would settle for good and routinely acquire citizenship, much as in the classic nations of immigrants that had long been the idealized model for Europe's fledgling immigration policies. In the meantime, the Gulf states' kafala system has shown an entirely different way for rich states to deal with labor migration, keeping it strictly temporary with a minimum of rights. This trend has acquired momentum even outside the Gulf region. By 2008, there were already 50 percent more temporary than permanent migrant workers entering a OECD country (ibid., 9). While this isn't that new for Europe with its "guest worker" legacy, it is new for Canada or Australia, which have fully embraced the general trend toward temporary migration. Hence

10 Boucher and Gest's notion of "migration regime" combines the immigrant selection and integration functions, and it is measured by the type of "visa mix" (work v. family v. humanitarian), the ration of temporary entries, and naturalization rates. 
Dauvergne's grim notion of the "end of settler societies", which have turned from a holistic "nation-building" to a narrowly "economic" view of migration $(2016,141)$.

In the new "market model" (Boucher and Guest 2018, ch.1), the New and the Old Worlds converge under a neoliberal arc. This model is labor-focused and restrictive on family migration; it favors temporary over permanent migration; it exhibits low naturalization rates and has a more narrow focus on rights; and it combines maximum flexibility for governments with deliberate instability for migrants. While the neoliberal pedigree of this model is obvious, Boucher and Guest also locate a nationalist element in it. This is because migrants who don't stay may assuage the mass public's "nativist and xenophobic" leanings (ibid., 6). As David Cook-Martin $(2019,1390)$ spelled out the logic, "nationalists" are fond of temporary migration, because it "will not affect the composition of the people"; at the same time, the fact that migrants are "affirmatively selected" under this model allows hiding its categorical exclusions. The market model thus "permits governments to have it both ways - effectively sanitizing globalization from its purported ills while enjoying the economic benefits that it brings" (Boucher and Gest 2018, 6).

\section{Courting the Top, Fending Off the Bottom: The Dual Structure of Neoliberal Immigration Policy}

Postwar migration regimes in Western states were typically distinguished as following either a guest-worker, a postcolonial, or a settler society logic (see Joppke 1999). Common to the guest-worker and postcolonial regimes, which were dominant in Europe, was the notion that the migrations processed by them were historically finite, and eventually to be reduced to zero. Germany, which had recruited "guest workers" from the late 1950s to the early 1970s, was the self-declared "kein Einwanderungsland» (no immigration country). But also Britain and France, more beholden to a postcolonial logic, pursued zero-immigration policies well into the 1990s. The global "race for talent" (Shachar 2006), starting with the onset of neoliberal globalization in the mid- to late-1990s, has rendered this anachronistic. Political elites throughout rich societies, including Singapore or South Korea, now agree that immigration is not a one-shot event but a recurrent process, required for economic or even demographic reasons. And its political processing, inclusive of the high-skilled top and restrictive of the low-skilled bottom, looks similar everywhere.

Indeed, immigration policy in a neoliberal context becomes bifurcated into a dual structure, even two separate policies, one of courting the top, in terms of soliciting high-skilled immigration, and another of fending off the bottom, which is to restrict low-skilled migration (whereby the latter closely overlaps with the restriction of asylum and family migration). This dual structure is affected by new nationalism only at the surface, not in essence. In fact, even the restrictiveness toward low-skilled 
migration, which one might suspect to be at least indirectly driven by nationalist concerns, is fully accountable within a neoliberal framework. This is because particularly family and asylum migration can be rejected for not "contributing", for being a welfare burden and cost factor to society. As Ruth Wodak $(2015,31)$ pointed out correctly, neoliberalism induces an "economization" of migration, in which the latter is reduced to a single cost-benefit consideration:

The discourse about migrants has been economized and is uncritically accepted by many: human beings don't matter in it but financial advantages or disadvantages in "our society" (do).

Crucially, as she observed, it is a short step from a neoliberal to an "inhumane" and xenophobic discourse that finds fertile ground in the radical right.

The logics of high- and low-skilled immigration policies are fundamentally different, so that it no longer makes sense, if it ever did, to conceive of immigration policy in the singular. The logic of high-skilled immigration policy is to proactively "solicit" flows where previously no flow existed, and which can never be large enough, also because of competition with other states. Accordingly, high-skilled immigration is almost never politicized, not even in countries with strong radical right parties and nationalist mobilization. By contrast, the logic of low-skilled migration policy is one of reactively "stemming" flows that precede the policy and notoriously exceed the demand for this type of migration, rendering it susceptible to chronic politicization by radical rightists. ${ }^{11}$ Another way of putting the matter is that "in regard to the unskilled, supply of immigrants exceeds demand in rich countries, and this fuels illegal immigration and flooding of false asylum entries into them", as political economist Jagdish Bhagwati formulates it $(2004,213)$. By contrast, "in regard to the skilled, demand exceeds supply in the rich countries", creating grievance mainly in the "poor countries (that) generally worry about having too many leave" (ibid.).

In a nutshell, low-skilled migration policy is by nature restrictive, even without any radical right input. At the same time, because in this case the flow precedes the policy, the latter is notoriously suspected of being not restrictive enough, which fuels the wheels of nationalist mobilization. By contrast, high-skilled immigration policy is the opposite of restrictive, because the policy precedes the flow and the numbers notoriously remain below expectation. Accordingly, high-skilled policy tends to be off the radar of politicization.

\subsection{Courting the Top: High-Skilled Immigration}

Selecting by merit and skill originated in the Canadian points system of 1967, followed by Australia twelve years later. In both cases, this replaced racially selective

11 For the "stemming" v. "soliciting" distinction and its implications for immigration policy, see Joppke $(2002 ; 2011)$. 
immigration policies. ${ }^{12}$ Interestingly, the original version of both points systems included subjective and personality-related features, dubbed "personal suitability" in Canada, which initially rewarded family ties with citizens for increasing immigrants' "adaptability". ${ }^{13}$ Non-economic criteria were subsequently removed or subordinated to "core employability factors" - the word in Australia for skill, age, and linguistic ability (Walsh 2011, 865). With their increasing emphasis on quantifiable human capital indicators, the points systems were "elevated as tools of neoliberal government" (ibid.).

In Europe, the turn to high-skilled immigration took off three decades later, coinciding with the rise of globalization, and in most cases it responded to acute labor shortages in the IT sector. The two pioneers are Germany and Britain, two previous champions of zero-immigration, and in both the turn occurred under “Third Way" left governments embracing a neoliberal agenda. In Britain, under Tony Blair, the buzzword was "managed migration". Never before had migration in Britain been framed as a tool of economic development. In a programmatic speech in September 2000, Home Office Minister Barbara Roche euphorically depicted the UK as "in competition for the brightest and best talents - the entrepreneurs, the scientists, the high technology specialists who make the global economy tick" (Cerna 2016, 159). By 2002, Britain had its Highly Skilled Migrants Program, Europe's first points system, which followed the Canadian model in its human capital orientation (i.e., not requiring a work contract), and it provided permanent residence after four (later five) years. While this system came to a factual (not legal) halt with Tory Prime Minister David Cameron's famous pledge to reduce immigration to the "tens of thousands", the Brexit-implementing government under Boris Johnson has renewed the commitment to a, now "Australian-style", points-based immigration system. ${ }^{14}$

A particularly interesting case is Germany. Responding to persistent industry complaints over Fachkräftemangel (shortage of skilled labor), the once "no immigration country" has established one of the most open high-skilled immigration policies of all OECD countries (see Kolb 2014, 68f). In a rather revolutionary move, a new migration law in 2005 (Zuwanderungsgesetz) introduced an immediate permanent residence permit for high-skilled immigrants. This broke with the European logic of Aufenthaltsverfestigung (residence consolidation), according to which permanent residence status was never immediate but had to be "earned" over time. But the real break-through came in 2012, in a law that implemented the EU Blue Card Directive for high-skilled immigrants in a most generous way. It waived the traditional labor market test, which had prioritized domestic workers, though it still demanded

12 This does not mean that racial or ethnic considerations would not continue to impinge on these policies, if only by subterfuge (see Ellermann and Goenaga 2019).

13 See "Canada's Immigration Policy: No Country for Old Men", The Economist, 10 January 2015, p. $42-43$.

See "Conservative Party Manifesto", The Guardian, 25 November 2019. 
a work contract that distinguishes European high-skilled policies from the more human-capital focused policies in Canada or Australia. However, entirely unrelated to the Blue Card implementation, the 2012 law also included the famous Article 18c. It allows any foreigner with a university degree to enter Germany to look for a job for the period of six months, albeit at his or her own cost and without the right to work in this period. This breached the otherwise strictly maintained work-contract requirement in the evolving German (and European) regime for high-skilled immigration, while adopting a Canadian-style human capital logic, as under the classic points system no work contract was required. With this bold move, the universityeducated part of humankind is entitled to put up tent in Germany. However, the fact that few have so far taken advantage of this, suggests that the word has not yet passed (see Finotelli and Kolb 2015, 6). The 2019 Fachkräfteeinwanderungsgesetz (Skilled Workers Immigration Law), the paradigm-changing first explicit "immigration law" in the history of the Federal Republic, has even extended the Article $18 \mathrm{c}$ logic further down the skill ladder, to qualified workers without a university degree. The legal-regulatory opening for skilled and high-skilled immigration has been so complete in Germany that only its "adequate marketing" is by now found wanting (SVR 2015, $17 \mathrm{f}$.).

At the same time, Canada has moved in the opposite direction, prioritizing temporary migration over permanent immigration, and adding employment criteria to its human-capital focused points system. A comparison of Canada and Germany's high-skilled migration policies thus found "more similarities than differences" between the two, registering in both countries the emergence of "hybrid systems" that mix human capital with employment- and occupation-based criteria (Kolb 2014, 57). ${ }^{15}$ Temporary migration and the requirement to hold a work contract, which tend to coincide, greatly increase the role of employers in the selection of migrants, while reducing the role of the state. This "advance(s) the neoliberal agenda" (Walsh 2014). As the Canadian Immigration Minister, Jason Kenney, expressed this shift colloquially, "employers are going to do a much better job at selection than a passive bureaucracy" (quoted by Lenard 2018, 226).

With the creation of a new Canadian Experience Class visa in 2007, a European-style "two-step" migration was introduced that emulates the principle of Aufenthaltsverfestigung, according to which permanent residence is acquired not from the start but only over time. This European principle is now standard in the classic immigration countries. The equivalent in the US is the H1-B visa for temporary high-skilled workers, introduced in 1990; the Australian equivalent is the 457 (Business) Visa introduced in 1996 (and replaced by a more demanding scheme in 2018) (see Birrell 2017). The point of two-step migration is to shift the burden and

15 Occupation-based selection prioritizes "shortage" professions, while employment-based selection requires a work contract. Both are to be distinguished from human-capital based selection, which prioritizes skills, language capacity, and age. 
the cost of integration entirely on migrants, because temporary migrants are not eligible for settlement services. And it allows a maximum of flexibility and a close linkage of labor migration with economic and labor market needs, which had not existed under a pure human-capital rewarding system. The trend toward a bigger role for employers in the selection process was completed with the Express Entry system, which Canada introduced in 2015, following New Zealand and Australia. The system makes a job offer the condition for being picked out of a pool of eligible high-skilled applicants. Never short of a catchy metaphor, Canadian immigration minister, Jason Kenney, likened it to a "dating service to connect employers with prospective immigrants". If previously the "talent for citizenship" was decisive, now a purely "commercial logic" rules over immigrant selection in Canada and other New World countries. Hence the "end of settlement", as diagnosed by Dauvergne (2016), which is also the end of the "Canadian Model" of a liberal-progressive immigration policy to be emulated by European states.

\subsection{Fending-Off the Bottom: The Many Faces of Low-Skilled Migration}

Low-skilled migration consists of two streams that need to be strictly separated: a small part that is legally processed as labor migration, and for which there are official programs in most rich countries, mostly under the umbrella of temporary or seasonal migration; and a major part where migrants are "low-skilled" not in a legal but factual (or presumed factual) sense, as in the case of (much of) family and asylum migration, but also of irregular migration. Accordingly, low-skilled migration has many faces and legal avenues of processing it. With respect to its majority non-labor part, it is at best a reasonable assumption that the migration processed through the family or asylum channels (or not processed at all, as in the irregular variant) is predominantly low-skilled. Furthermore, the legally non-labor portion of low-skilled migration is distinct as being "unwanted" in an analytical sense. It occurs not because of an interest on part of the state, as it is the case in labor migration, but because of recognition of a right on part of the migrant or of a resident or citizen, as in asylum and family migration, respectively; or it simply comes about due to a control failure of the state, as in irregular migration.

With respect to labor migration, Martin Ruhs (2013) argued conclusively that "high-income countries" are more open to high-skilled immigrants, if only because they pay more taxes and are not likely to use social services. Conversely, "(m)ajor migrant-receiving states have no overwhelming interests in more low-skilled labor migration" (Kuptsch and Martin 2011, 52). If the latter is accepted in larger numbers, it is at the price of lesser rights. Philip Martin (2006) has described the opposing treatment of high- v. low-skilled labor migrants as "red carpet" v. "red card", or "Welcome the Skilled, Rotate the Unskilled". The catchy formula suggests that temporariness ("rotate"), while increasingly a feature of high-skilled migration as well, is structurally woven into the processing of low-skilled migration. The latter 
is almost by definition "temporary and seasonal” (Hampshire 2013, 61), as already the classic notion of "guest worker" had implied. If the temporariness of "guest worker" schemes tends to be more strictly observed today than in the past, at least at the level of policy intention, this reflects the factoring in of political opposition to migration, which has become epidemic in times of populism. In James Hampshire's formulation (ibid., 62), temporariness helps "avoiding both the political risks of permanent immigration and the social costs of integrating long-term immigrants."

Second-class or "red card" treatment of low-skilled migrants is possible without much ado in countries without a human rights tradition and without strong domestic equality norms, such as the Gulf States or Singapore. These countries admit low-skilled migrants in huge numbers but systematically prevent them from settling down and even keep them apart as a lower caste that must not mingle or bond with natives. Such a stance is more difficult, if not impossible, in Western states beholden to human rights and equality norms. Philip Martin (2006) has formulated the dilemma well:

The fundamental issue is that migration is motivated by differences, but migrant conventions call for equality. If migrants were truly "equal" in receiving countries, fewer would be demanded, as exemplified by mechanization in agriculture when wages rise.

If "equal participation" (gleiche Teilhabe) (SVR 2018, 70) is the liberal-progressive lodestar of immigrant integration in Western states, it is organized hypocrisy. Because without inequality there wouldn't be migration at all - at least to the degree that the latter is low-skilled labor migration. The fact of lesser rights is circularly involved as cause and regulatory frame of this migration.

The likelihood of being low-skilled or even unproductive and social-benefit claiming, is one of the reasons why family migration, in particular, has been on the restrictive radar of Western governments. In Europe, this has been the case since the closing-down of guest worker migration in the early 1970s. The linkage between "family" and "low-skilled" is a simple network effect, "reflect(ing) past large-scale recruitment of low-skilled migrants" (Bonjour and Kraler 2015, 1416), who later ask to be joined by a spouse or children. At the same time, it goes without saying that recruiting high-skilled immigrants requires granting them family rights that are not affected by these restrictive moves.

But even in Canada, as it turned toward a neoliberal immigration policy, favoring temporary migration over permanent immigration, a "systematic discounting of family-based migration" (Root et al. 2014, 68) can be registered, despite the fact that in this case the network effect had to be positive (because, apart from refugees, only high-skilled migrants have a chance to be selected in the first). Under the conservative Harper government (2006-2015), the age limit for "dependent children" was lowered from "under 22" to "under 19", and exceptions for "over 18s" who 
are full-time students were removed. During their first two years, the permanent residency for sponsored spouses was made conditional. In addition, new applications by parents and grandparents within the family reunification program were first suspended for two years, what increased waiting times to eight years; thereafter they were capped at the very small number of 5000 per year, which further increased the backlog. Moreover, the sponsors' required income level was raised by 30 percent, and they had to cover income support costs for the first 20 (instead of 10) years of residency. At the same time, a multiple-entry "Super Visa" over a maximum period of 10 years was introduced for parents and grandparents, which required the purchase of a one-year health insurance even for much shorter visits (see Chen and Thorpe 2015). These restrictive family migration measures were to forfeit an "abuse of Canada's generosity", as Immigration Minister Jason Kenney explains (Forcier and Dufour 2016, 5). He did not hide the neoliberal underpinnings of his attack on extended family migration:

\section{There have to be practical limits to our generosity. We have to calibrate... limits based on our country's economic needs, our fiscal capacity. There is no doubt that people who are coming who are senior citizens, they have much, much lower labour-market participation and much higher levels of utilization of the public health system. (Root et al. 2014, 67)}

In Europe, a new chapter and rationale of reducing family migration started under French Interior Minister Nicolas Sarkozy in 2005, who launched a programmatic move from "suffered" to "chosen" immigration. Importantly, this meant abandoning the zero immigration objective that had undergirded French (and other European states') policy (or policies) up to this point. According to Sarkozy, zero-immigration had become anachronistic in light of "new economic and demographic needs" ${ }^{16}$ Yet this opening was to occur within a zero-sum frame of replacing unwanted family immigration with wanted high-skilled immigration. In Sarkozy's terms, a "better equilibrium" between "work" and "as of right" immigration had to be achieved. ${ }^{17}$ This was a euphemism, because his instruction, after gaining the Presidency in 2007, to move the labor-to-family migration ratio from the present 10:90 to 50:50, was Mission Impossible, not least due to legal-constitutional constraints (see Fassin 2009). Sarkozy had a point, however. France had (and still has) one of the lowest levels of labor migration in Europe, with just 5.8 percent of all legal intakes in 2006 (Kofman et al. 2010, 17). At the same time, the French rate of family migration is one of the highest in Europe, with almost 60 percent of legal inflows in 2006 (Joppke 2011, 236). Most of this intake hails from North Africa and Turkey, in numbers

16 «Déclaration de M. Nicolas Sarkozy», French National Assembly, 9 June 2005 (http://discours. vie-publique.fr/notices/053001871.html). Ibid. 
that even exceed intra-EU flows, and the bulk of it is low-skilled, entailing a high level of unemployment and welfare dependency.

Incidentally, Sarkozy announced his new immigration policy shortly after French voters had rejected the EU constitution draft in late May 2005. He took this vote as rejection of the "globalization" that, he believed, was associated with "Europe":

This vote is the expression of a deep crisis of mistrust: mistrust of the capacity of Europe to get the best out of globalization, while assuring protection against unemployment, dislocation, suffered immigration, terrorism; mistrust of France's capacity to maintain its place in the European competition. ${ }^{18}$

Obviously, popular fears of neoliberalism had to be reconciled with a neoliberal immigration policy that envisaged the "circulation of brains, in a win-win situation for receiving and sending countries". ${ }^{19}$ Therefore it was important, and not a small rhetorical feat on the part of Sarkozy, to present a neoliberal immigration policy as an "expression of France's sovereignty", a "choice" - implying an exact reversal of the usual framing of neoliberalism, which is that "there is no alternative", in the famous words of Margaret Thatcher. And it was important to back up this "choice" with firm action against a family reunification that, while corresponding to "our values" and a "right" protected by the constitution, was still deemed "out of balance" and marred by "numerous frauds", in particular "marriages of convenience" and "forced marriages". ${ }^{20}$

However, the move toward restricting family migration should not be seen as attempt to preempt the radical right that has been traditionally strong in France. Sarkozy would do that only later in his Presidency, and then with gusto. Instead, this restriction occurred in a rather progressive context of optimizing "Republican integration" through bringing about "equality of chances" for immigrant minorities, which included ambitious plans for "positive discrimination" (which never saw the light of day). ${ }^{21}$

Eventually, in laws passed in 2006 and 2007, the French government adopted the typical array of restrictive measures against family immigration which other Western European countries would (or already had) adopt(ed) at that time, including raising the minimum legal residence period of sponsors and requiring financial independence and sufficient housing on their part, while introducing an "integration from abroad" test for the migrant spouse. From 2006 to 2007, with some of these measures in place, the number of French residence permits for family reunion indeed decreased by almost 11 percent (Fassin 2009). However, the intended 50:50 workto-family ratio could not even remotely be achieved. In 2010, 86000 new family

\begin{tabular}{ll}
\hline 18 & Ibid. \\
19 & Ibid. \\
20 & Ibid. \\
21 & Ibid.
\end{tabular}


migrants stood against only 24000 labor migrants (Cerna 2016, 216); in 2015, the number of new family migrants was even up to 104000 (SOPEMI 2017, 113).

In the end, the move from suffered to chosen immigration never materialized, neither in France nor elsewhere in Europe. Family reunification, in combination with asylum seeking, have remained the "major avenues of immigration in Europe" (Hollifield et al. 2019, 13). Constitutional obstacles to restrict as-of-right migration, as well as the inertia of established migration systems, proved too strong. However, the persistent impulse to restrict the many faces of low-skilled migration, which predates the rise of the radical right, is decisive.

\section{Marginal Neonationalism}

Neonationalism, carried by a new brand of populist radical right parties and movements, may be seen as the main opposition force to neoliberal globalization, advocating "closure" against the most drastic "opening" that human societies have possibly ever experienced, and thus signaling a new cleavage in political life. In particular, immigration and the cultural changes brought by it preoccupy these parties (see Goodhart 2017). Hence the question: What impact have they had on immigration policy?

The first thing we notice is that in Western Europe radical right parties are always minority parties, with an average share of under 18 percent of the vote in 2017 (Eiermann et al. 2018, 13). This naturally limits their impact. One review found them "dogs that bark loud, but hardly ever bite" (Mudde 2013, 14), particularly as they mainly address "sociocultural" issues that remain peripheral to mainstream parties' continued preoccupation with socioeconomics. Writing earlier in the millennium, Tim Bale (2008) pointed out that mainstream center-right parties had taken restrictive positions on immigration long before radical right parties were put on the map. In his view, there had never been a "conspiracy of silence" between center-right and center-left parties on immigration, as claimed by some (e. g. Freeman 1995). Just consider Britain's panicky closing of New Commonwealth immigration in the 1960s, Thatcher's fear of being "swamped" in the late 1970s, and a "firm" British immigration and asylum-policy geared toward zero-immigration well into the late 1990s; or consider the 1980s' hard-lining against family migration by German Interior Minister Friedrich Zimmermann (of the Bavarian CSU); and, not to forget, the 1990s' explicit "zero-immigration" policy of French Interior Minister Charles Pasqua (UMP). These are merely examples from Europe's Big Three. When radical right mobilizing was not remotely as strong as it is today, Rogers Brubaker (1995:908) already depicted European immigration policy as "chronically populist" - notably in a rebuttal of Gary Freeman's by now classic liberal thesis (1995). 
However, it is difficult to deny "contagion by the right" (Norris 2005), as the cordon sanitaire that once separated radical right parties from center-right parties is lifted in more and more countries. This is most notably the case in the Netherlands and Denmark, whose immigration policies have been in the thrall of the radical right for much of the new millennium. A Europe-wide review in 2018 found that "populists are no longer shunned by the democratic mainstream as a matter of course; they are increasingly called into coalitions, co-opted and copied". ${ }^{22}$ The number of European governments with populist participation has increased from 7 in 2000 to 14 by February 2018. ${ }^{23}$ In principle, it is possible for radical right parties to be "moderated" as they move closer to power. In practice, however, as a study of party manifestos of 68 parties in 17 European countries between 1980 and 2014 found, mainstream parties, notably of the right and left alike, have increasingly "accommodated" radical right demands, particularly on their signature docket of "liberal-authoritarian" issues (which includes immigration, minorities, and law and order) (Wagner and Meyer 2018). This accommodation has been in terms of mainstream parties" "positions taken" and the "salience" given to them. Astoundingly, "the mean position of the mainstream left today is about as authoritarian as the mean radical right position in the 1980s" (ibid., 92). The study concludes that "the old radical right programmatic orientations have become the "new normal"" (ibid., 99), while radical right parties have moved even further to the right. At the same time, however, a recent analysis of mainstream party manifestos in 12 Western European countries, between the early 1960s and 2013, found "little evidence that (anti-immigrant parties) dictate or even influence how centrist parties address the topic (of immigration)" (Dancygier and Margalit 2019:33). The jury over the degree of radical right influence seems to be out. But the fact that family reunification and asylum policy were on a restrictive path as early as the 1980s, preceding the rise of the radical right and of populism, still stands.

But what about the two neonationalist breakthrough events in the West, Brexit and Trump, in both of which opposition to immigration was key? Are they changing the structure of immigration policy as depicted above? The answer is no.

The successful Brexit referendum of June 2016 was fundamentally a populistnationalist reaction to a (neo)liberal immigration policy gone astray, in terms of accepting high numbers of migrants, predominantly from the new eastern member states of the EU, that were far above the limit of what was commonly held acceptable. But it does not change the quality or structure of immigration policy. Post-Brexit, the UK will embrace the typical combination of soliciting high-skilled while restricting low-skilled migration, under the umbrella of an Australia-modelled "points-based system" (see MAC 2020). As there is no longer favoritism for other Europeans, Brit-

22 "A Dangerous Waltz", The Economist, 3 February 2018, p. 17.

23 Ibid., p. 18. Shortly thereafter the number increased to 15, with Italy's all-populist coalition government which was formed in spring 2018 (but collapsed in the summer of the following year). 
ish immigration policy will even become less "racist" and more liberal-universalistic. As Brexit advocate Michael Gove put it slyly, "outside the EU we can have a truly colour-blind migration policy that ... treats people from the Bahamas in the same way as we treat people from Bulgaria”. ${ }^{24}$

By contrast, the rise of Trump does imply a threat to the liberal basis of immigration policy, which has otherwise remained intact in a neoliberal context: It breaches the "anti-populist norm" (Freeman 1995), which is the elite taboo to address the ethno-racial composition of migrant intakes with negatively discriminatory intent. However, Trump's immigration policy, particularly its animus against illegal immigrants, only radicalized the enforcement turn that US immigration policy has taken since the days of Democratic President Clinton (see Wong 2017). No legislative changes were necessary for even the most drastic of Trump's measures, such as separating families at the Mexican border. And the "Muslim Ban", which is the most radical of all neonationalist interventions in a Western state's immigration policy to date, passed constitutional muster only once it was transformed into a religiously and ethno-racially anonymous "Travel Ban" (see Spiro 2019), however hollow and hypocritical this transformation may have been. While immigration policy was the only domain where a plutocratic president lived up to his populist promises, pluralist American institutions, above all independent courts, have overall held the line against a populist-nationalist Durchmarsch.

\section{Conclusion}

Any reflection on immigration policy, past and present, must start with the restrictive imperative that is constitutive of it. Catherine Dauvergne $(2016,72)$ captured it succinctly: "It is impossible for immigration law to fully embrace a liberal paradigm because of its role in constituting the border". In this spirit, this paper laid out the dual structure of immigration policy (or rather policies) in the neoliberal era, and tried to assess the difference that neonationalism makes. There are two main messages. First, neonationalism has only tangentially touched on the bifurcated structure of neoliberal immigration policy. It largely ignored the latter's "courting the top" prong, sometimes even supporting it, while seeking to lend more severity to the "fending off the bottom" exercise. The crucial matter is that neonationalism has not initiated the restrictiveness against low-skilled migration, which can be accounted for in neoliberal terms. Secondly, there is little transatlantic variation to neoliberal immigration policy. The days of the "American" or "Canadian model" of a liberal and inclusive, settlement-oriented immigration policy are over. This transatlantic convergence is demonstrated by a new proclivity for temporary migration, pertaining

24 https:/www.bbc.com/news/uk-politics-43821484. 
even to the high-skilled, in the classic nations of immigrants, as well as by similarly restrictive approaches to family migration.

Liberalism, neoliberalism, and nationalism are the three central ideological forces that shape Western states' immigration policies of our time, and the challenge is to calibrate the three, without forgetting that their constellation is not the same in any two places or times. While I characterized the dualism of courting the top and fending-off the bottom as "neoliberal", this does not mean that the other two elements are absent. A restrictive imperative, articulating a kind of structural nationalism to keep states as bounded entities, undergirds all immigration policy. This is perhaps why the neonationalism factor, which some critical analysts have also looked up under closely related flags like "racialization" or "securitization", is so tangential: It tries to further shut a door that is already (relatively) shut. Neonationalists would really cut ice if there was a return from individual- to group-level, from merit-based to origin-based immigration policies, as they had been in the first half of the $20^{\text {th }}$ century. While there was a glimmer of this in Trump's Muslim Ban, a basic non-discrimination norm continued to be observed, and in this basic sense immigration policy continued to be liberal, even in Trump's America. Accordingly, the liberalism factor is never to forget. The neoliberalism factor was simply highlighted here because it best accounts for the ambivalent (or dual) nature of contemporary immigration policies that are selectively open for the high-skilled but (relatively) closed for all others, the common denominator of both policy prongs being economic utility and a cost rationale. A task of future research would be a fuller account of the often paradoxical relationships between (neo)liberalism and neonationalism, which range from oppositional to complementary. Note that neonationalists are at the most effective when eschewing ethnicity or racial in favor of (neo)liberal rhetoric, attacking certain immigrants for their presumed incompatibility with liberal values or for not "contributing" (see Halikiopoulou and Vlandas 2019).

\section{$7 \quad$ References}

AfD. 2017. Programm für Deutschland. Cologne.

Bale, Tim. 2008. Turning Round the Telescope. Journal of European Public Policy 15(3): 315-330.

Bhagwati, Jagdish. 2004. In Defense of Globalization. New York: Oxford University Press.

Birrell, Bob. 2017. The Coalition's 457 Visa Reset. Victoria: Australian Population Research Institute, Monash University.

Bonjour, Saskia and Albert Kraler. 2015. Family Migration as an Integration Issue? Journal of Family Issues 36(11): 1407-1432.

Boucher, Anna, and Justin Gest. 2018. Crossroads: Comparative Immigration Regimes in a World of Demographic Change. New York: Cambridge University Press.

Brown, Wendy. 2015. Undoing the Demos: Neoliberalism's Stealth Revolution. New York: Zone Books.

Brubaker, Rogers. 1995. Comments on Freeman. International Migration Review 29(4): 903-908. 
Careja, Roman et al. 2016. Direct and Indirect Welfare Chauvinism as Party Strategies. Scandinavian Political Studies 39(4): 435-457.

Cerna, Lucie. 2016. Immigration Policies and the Global Competition for Talent. London: Palgrave.

Chen, Xiaobei, and Sherry Thorpe. 2015. Temporary Families? Migration, Mobility, and Displacement 1(1): 81-98.

Cook-Martin, David. 2019. Temp Nations. American Behavioral Scientist 63(9): 1389-1403.

Dancygier, Rafaela, and Yotam Margalit. 2019. The Evolution of the Immigration Debate. Comparative Political Studies (advanced electronic publication): 1-41.

Dauvergne, Catherine. 2016. The New Politics of Immigration and the End of Settler Societies. New York: Cambridge University Press.

De Haas, Hein, Natter, Katharina, and Simona Vezzoli. 2016. Growing Restrictiveness or Changing Selection? International Migration Review 52(2): 324-367.

Eiermann, Martin, Mounk, Yascha, and Limor Gultchin. 2017. European Populism. Tony Blair Institute for Global Change.

Ellermann, Antje and Agustin Goenaga. 2019. Discrimination and Policies of Immigrant Selection in Liberal States. Politics and Society 47(1): 87-116.

Fassin, Eric. 2009. Immigration subie. P. 22 in Le Monde Diplomatique, November.

Finotelli, Claudia, and Holger Kolb. 2015. "The Good, the Bad and the Ugly" Reconsidered. Journal of Comparative Policy Analysis (advanced electronic publication): 1-15.

FN (Front National). 2017. Marine 2017: 144 engagements présidentiels. (https://rassemblementnational. $\mathrm{fr} / \mathrm{pdf} / 144$-engagements.pdf).

Forcier, Mathieu, and Frédérick G. Dufour. 2016. Immigration, Neoconservatism and Neoliberalism. Cogent Social Sciences 2(1): 1-18.

FPÖ. 2017. Österreicher verdienen Fairness. Vienna.

Freeman, Gary P. 1995. Modes of Immigration Politics in Liberal Democratic States. International Migration Review 29(4): 881-902.

Freeman, Richard B. 2006. People Flows in Globalization. Journal of Economic Perspectives 20(2): 145-170.

Goodhart, David. 2017. The Road to Somewhere. London: Hurst.

Halikiopoulou, Daphne, and Tim Vlandas. 2019. What is New and What is Nationalist About Europe's New Nationalism? Nations and Nationalism 25(2): 409-434.

Hampshire, James. 2013. The Politics of Immigration. Cambridge: Polity.

Hayek, Friedrich. 1982. The Mirage of Social Justice. London: Routledge.

Hollifield, James F., Philip L. Martin, and Pia M. Orrenius. 2019. Introduction: The Dilemmas of Immigration Control (typescript, in author's possession). For a new edition of Controlling Immigration (Stanford, Calif.: Stanford University Press, forthcoming).

Joppke, Christian. 1999. Immigration and the Nation-State. Oxford: Oxford University Press.

Joppke, Christian. 2002. European Immigration Policies at the Crossroads. Pp. 259-276 in Developments in West European Politics 2, edited by Paul Heywood et al. London: Palgrave.

Joppke, Christian. 2005. Selecting by Origin. Cambridge, Mass.: Harvard University Press.

Joppke, Christian. 2011. European Immigration Policies. Pp . 220-240 in Developments in European Politics 2, edited by Paul Heywood et al. London: Palgrave.

Kleven, Henrik Jacobsen, Landais, Camille, Saez, Emmanuel, and Esben Anton Schultz. 2014. Migration and Wage Effects of Taxing Top Earners. Quarterly Journal for Economics 129(1): 333-378.

Kofman, Eleonore, Madalina Rogoz, and Florence Lévey. 2010. Family Migration Policies in Europe. Unpublished manuscript (in author's possession). 
Kolb, Holger. 2014. When Extremes Converge. Comparative Migration Studies (2(1): 57-75.

Kuptsch, Christiane and Philip Martin. 2011. Low-Skilled Labour Migration. Pp. 34-59 in Global Migration Governance, edited by Alexander Betts. Oxford: Oxford University Press.

Lenard, Patti Tamara. 2018. Wither the Canadian Model? Pp. 211-236 in Diversity and Contestations Over Nationalism in Europe and Canada, edited by John Erik Fossum et al. London: Palgrave.

MAC. 2020. A Points-Based System and Salary Thresholds for Immigration. London, January.

Macklin, Audrey. 2017. From Settler Society to Warrior Nation and Back Again. Pp. 258-313 in Citizenship in Transnational Perspective, edited by Jatinder Mann. London: Palgrave.

Martin, Philip. 2006. The Economics of Migration. Harvard International Review, 17 July.

Massey, Douglas, Arango, Joaquin, Hugo, Graeme, Kouaouci, Ali, Pellegrino, Adela, and J. Edward Taylor. 1993. Theories of International Migration. Population and Development Review 19(3): 431-466.

Mudde, Cas. 2013. Three Decades of Populist Radical Right Parties in Western Europe. European Journal of Political Research 52: 1-19.

Norris, Pippa. 2005. Radical Right. New York: Cambridge University Press.

Peters, Margaret. 2017. Trading Barriers. Princeton, N. J.: Princeton University Press.

Root, Jesse, Gates-Gasse, Erika, Shields, John, and Harald Bauder. 2014. Discounting Immigrant Families: Neoliberalism and the Framing of Canadian Immigration Policy Change. Toronto: Ryerson University, RCIS Working Paper 2014/7.

Ruhs, Martin. 2013. The Price of Rights. Princeton, N. J.: Princeton University Press.

Shachar, Ayelet. 2006. The Race for Talent. NYU Law Review 81: 148-206.

Shachar, Ayelet. 2016. Selecting by Merit. Pp. 175-204 in Migration in Political Theory, edited by Sarah Fine and Lea Ypi. Oxford: Oxford University Press.

Sidgwick, Henry. 1891. The Elements of Politics. London: Macmillan.

SOPEMI. 2017. International Migration Outlook. Paris: OECD.

Spiro, Peter. 2019. Trump v. Hawaii, 138 S. Ct. 2302. American Journal of International Law 113(1): $109-116$.

SVR (Sachverständigenrat deutscher Stiftungen für Integration und Migration). 2015. Unter Einwanderungsländern: Jahresgutachten 2015. Berlin.

SVR. 2018. Steuern, was zu steuern ist: Jahresgutachten 2018. Berlin.

SVR. 2019. Bewegte Zeiten: Jahresgutachten 2019. Berlin.

Wagner, Markus, and Thomas Meyer. 2017. The Radical Right as Niche Parties? Political Studies 65(15): 84-107.

Walsh, James. 2011. Quantifying Citizens. Citizenship Studies 15(6-7): 861-879.

Walsh, James. 2014. From Nations of Immigrants to States of Transience. International Sociology 20(6): 584-606.

Wodak, Ruth. 2015. Normalisierung nach rechts. Linguistik Online 73(4-5): 27-44.

Wong, Tom K. 2017. The Politics of Immigration: Partisanship, Demographic Change, and American National Identity. New York: Oxford University Press.

Zolberg, Aristide. 2006. A Nation by Design. Cambridge, Mass.: Russell Sage Foundation and Harvard University Press. 